\title{
Bioactive selaginellins from Selaginella tamariscina (Beauv.) Spring
}

Chao Yang ${ }^{* 1,2}$, Yutian Shao ${ }^{1}$, Kang $\mathrm{Li}^{1}$ and Wujiong $\mathrm{Xia}^{1}$

\section{Letter}

Address:
1State Key Lab of Urban Water Resource and Environment \& the
Academy of Fundamental and Interdisciplinary Sciences, Harbin
Institute of Technology, Harbin 150080, PR China and 'State Key Lab
of Applied Organic Chemistry, Lanzhou University, Lanzhou 730000, PR China

Email:

Chao Yang ${ }^{*}$ - xyyang@hit.edu.cn

* Corresponding author

Keywords:

antioxidant; cytotoxicity; Selaginella tamariscina; selaginellin

\author{
Beilstein J. Org. Chem. 2012, 8, 1884-1889. \\ doi:10.3762/bjoc.8.217 \\ Received: 06 July 2012 \\ Accepted: 08 October 2012 \\ Published: 05 November 2012 \\ Associate Editor: A. Kirschning \\ () 2012 Yang et al; licensee Beilstein-Institut. \\ License and terms: see end of document.
}

\begin{abstract}
A new selaginellin named selaginellin O (1), along with three other known selaginellins (2-4) were isolated from Selaginella tamariscina (Beauv.) Spring. On the basis of spectroscopic analysis, the structure of selaginellin $\mathrm{O}$ was demonstrated to be 4-[(4'hydroxy-4-formyl-3-((4-hydroxyphenyl)ethynyl)biphenyl-2-yl)(4-hydroxyphenyl)methylene]cyclohexa-2,5-dien-1-one. Compound 1, 2 and $\mathbf{3}$ exhibited appreciable cytotoxic activity against cultured HeLa cells (human cervical carcinoma cells), as well as significant antioxidant activity.
\end{abstract}

\section{Introduction}

There are about 700 species of the genus Selaginella (family selaginellacea) widely found in the world, with more than 50 species being found in China [1]. Twenty of them are widely used in Chinese folk medicine, most frequently employed for the treatment of cancer, cardiovascular problems, hepatitis, gastritis, hematuria, diabetes, and skin diseases [2]. Selaginella tamariscina (Beauv.) Spring is one of the two qualified species listed in Chinese Pharmacopoeia that has long been used as a traditional Chinese medicine for promoting blood circulation [3]. Phytochemical and pharmacological studies on genus Selaginella led to identifications of numerous bioactive com- pounds, including biflavonoids, alkaloids, and lignans, with broad biological activities, including antivirus, antifungal, antibacterial, cytotoxic, and anti-inflammatory properties [4-20]. In the past five years, more than 10 selaginellins (novel pigments with a unique para-quinone methide and alkynylphenol carbon skeleton) have been isolated from several Selaginella species in China [13-20]. Selaginellin derivatives have been hitherto found only in genus Selaginella. In the course of our phytochemical investigations on Selaginella tamariscina (Beauv.) Spring, four selaginellin derivatives (Figure 1), namely selaginellin M (2) [20], selaginellin (3) [13], 


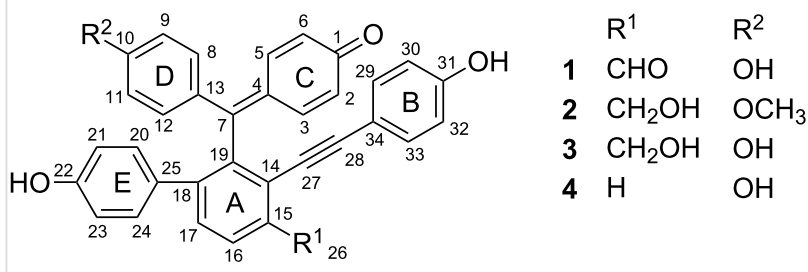

Figure 1: Structures of selaginellins from S. tamariscina.

selaginellin A (4) [14], and a new analogue selaginellin O (1), were isolated from the entire plant. Herein, we report the isolation and structural elucidation of these selaginellin derivatives, as well as the evaluation of their bioactivities.

\section{Results and Discussion}

Selaginellin O (1), was obtained as a red powder, with the molecular formula $\mathrm{C}_{34} \mathrm{H}_{22} \mathrm{O}_{5}$, deduced from HRMS-ESI on the basis of the quasi-molecular ion peak at $m / z 511.1543[\mathrm{M}+\mathrm{H}]^{+}$ (calcd 511.1540). The IR spectrum indicated absorption bands for hydroxyl $\left(3378 \mathrm{~cm}^{-1}\right)$, formyl $\left(2829,2817,1726 \mathrm{~cm}^{-1}\right)$, alkynyl $\left(2198 \mathrm{~cm}^{-1}\right)$, unsaturated carboxyl $\left(1680 \mathrm{~cm}^{-1}\right)$ and aromatic ring (1570 and $1524 \mathrm{~cm}^{-1}$ ).

The assignment of all ${ }^{1} \mathrm{H}$ and ${ }^{13} \mathrm{C}$ NMR data (shown in Table 1) was confirmed by 2D NMR techniques. The NMR spectra of $\mathbf{1}$ showed the typical signals of a formyl group $\left(\delta_{\mathrm{H}} 10.73\right.$ and $\delta_{\mathrm{C}}$ $190.9)$, an alkynyl band $\left(\delta_{C} 82.4,101.0\right)$, three phenolic hydroxyl $\left(\delta_{\mathrm{H}} 8.94\right.$ and 8.59$)$, and five aromatic rings, including one AB-spin system $\left(\delta_{\mathrm{H}} 7.52\right.$ and 8.05 , each $\left.1 \mathrm{H}, \mathrm{d}, J=8.0 \mathrm{~Hz}\right)$ for the ortho-tetrasubstituted A-ring, three AA'BB' systems $\left(\delta_{\mathrm{H}}\right.$ 7.22 and 6.78 , each $2 \mathrm{H}, \mathrm{d}, J=8.4 \mathrm{~Hz}),\left(\delta_{\mathrm{H}} 6.87\right.$ and 6.71 , each $2 \mathrm{H}, \mathrm{d}, J=8.4 \mathrm{~Hz})$ and $\left(\delta_{\mathrm{H}} 6.96\right.$ and 6.70 , each $2 \mathrm{H}, \mathrm{d}, J=$ $8.4 \mathrm{~Hz}$ ) for the respective para-substituted B-, D- and E-ring, and one ABMN system $\left(\delta_{\mathrm{H}} 7.61,7.42,6.41\right.$ and 6.35 , each $1 \mathrm{H}$, $\mathrm{d}, J=10.0 \mathrm{~Hz}$ ) for the C-ring. The above structural features suggested 1 was a selaginellin with a formyl group. Key evidence for the structure of $\mathbf{1}$ obtained from the HMBC experiment further confirmed this suggestion (Figure 2). The HMBC correlations H16/C-26 and H-26/C-15 concluded the substitution of the formyl group at C-15 of the A-ring. The alkynyl group was connected to the B-ring based on correlations between H-29,33 and C-28. The linkage between the C-ring and the B-ring was located at $\mathrm{C}-7$ demonstrated by the HMBC cross-peaks of H-3,5/C-7 and H-8,12/C-7. The E-ring was connected to the A-ring at $\mathrm{C}-18$ due to $\mathrm{HMBC}$ correlations $\mathrm{H}-20,24 / \mathrm{C}-18$ and H-17/C-25. Hence, C-19 in the A-ring was the position left for C-7. Consequently, the structure of compound 1 was characterized as 4-[(4'-hydroxy-4-formyl-3-((4-
Table 1: ${ }^{1} \mathrm{H}$ and ${ }^{13} \mathrm{C}$ NMR data and key HMBC correlations for compound 1 . $^{\text {a }}$

\begin{tabular}{|c|c|c|c|c|}
\hline Position & $\delta_{\mathrm{H}}$ & $\delta_{C}$ & (DEPT) & $\mathrm{HMBC}(\mathrm{H} \rightarrow \mathrm{C})$ \\
\hline 1 & - & 185.6 & $(q C)$ & - \\
\hline 2 & $6.35 \mathrm{~d}(10.0)$ & 128.4 & $(\mathrm{CH})$ & C-4 \\
\hline 3 & $7.42 \mathrm{~d}(9.6)$ & 139.2 & $(\mathrm{CH})$ & C- 1,7 \\
\hline 4 & - & 131.4 & $(q C)$ & - \\
\hline 5 & $7.61 \mathrm{~d}(9.6)$ & 138.1 & $(\mathrm{CH})$ & $C-1,7$ \\
\hline 6 & $6.41 \mathrm{~d}(10.0)$ & 128.5 & $(\mathrm{CH})$ & C-4 \\
\hline 7 & - & 156.3 & $(q C)$ & - \\
\hline 8 & $6.87 \mathrm{~d}(8.4)$ & 133.0 & $(\mathrm{CH})$ & C-7,10 \\
\hline 9 & $6.71 \mathrm{~d}(8.4)$ & 114.9 & $(\mathrm{CH})$ & $\mathrm{C}-13$ \\
\hline 10 & - & 158.8 & $(q C)$ & - \\
\hline 11 & $6.71 \mathrm{~d}(8.4)$ & 114.9 & $(\mathrm{CH})$ & C-13 \\
\hline 12 & $6.87 \mathrm{~d}(8.4)$ & 133.0 & $(\mathrm{CH})$ & $C-7,10$ \\
\hline 13 & - & 131.4 & $(q C)$ & - \\
\hline 14 & - & 127.7 & $(q C)$ & - \\
\hline 15 & - & 134.2 & $(q C)$ & - \\
\hline 16 & $8.05 \mathrm{~d}(8.0)$ & 127.5 & $(\mathrm{CH})$ & C- $14,18,26$ \\
\hline 17 & $7.52 \mathrm{~d}(8.0)$ & 130.1 & $(\mathrm{CH})$ & C- $15,19,25$ \\
\hline 18 & - & 148.1 & $(q C)$ & - \\
\hline 19 & - & 142.3 & $(q C)$ & - \\
\hline 20 & $6.96 \mathrm{~d}(8.4)$ & 129.8 & $(\mathrm{CH})$ & $C-18,22$ \\
\hline 21 & $6.70 \mathrm{~d}(8.4)$ & 114.9 & $(\mathrm{CH})$ & C-25 \\
\hline 22 & - & 157.4 & $(q C)$ & - \\
\hline 23 & $6.70 \mathrm{~d}(8.4)$ & 114.9 & $(\mathrm{CH})$ & C-25 \\
\hline 24 & $6.96 \mathrm{~d}(8.4)$ & 129.8 & $(\mathrm{CH})$ & C-18, 22 \\
\hline 25 & - & 130.8 & $(q C)$ & - \\
\hline 26 & $10.73 \mathrm{~s}$ & 190.9 & $(\mathrm{CH})$ & $\mathrm{C}-14,16$ \\
\hline 27 & - & 82.4 & $(q C)$ & - \\
\hline 28 & - & 101.0 & $(q C)$ & - \\
\hline 29 & $7.22 \mathrm{~d}(8.4)$ & 133.5 & $(\mathrm{CH})$ & C-28, 31 \\
\hline 30 & $6.78 \mathrm{~d}(8.4)$ & 115.6 & $(\mathrm{CH})$ & C-34 \\
\hline 31 & - & 158.7 & $(q C)$ & - \\
\hline 32 & $6.78 \mathrm{~d}(8.4)$ & 115.6 & $(\mathrm{CH})$ & C-34 \\
\hline 33 & $7.22 \mathrm{~d}(8.4)$ & 133.5 & $(\mathrm{CH})$ & C-28, 31 \\
\hline 34 & - & 112.5 & $(q C)$ & - \\
\hline $10-\mathrm{OH}$ & $8.94(b r)^{b}$ & & & C-9, 11 \\
\hline $22-\mathrm{OH}$ & $8.59(b r)$ & & & $\mathrm{C}-21,23$ \\
\hline $31-\mathrm{OH}$ & $8.94(b r)^{b}$ & & & C-30, 32 \\
\hline
\end{tabular}

a $400 \mathrm{MHz}$, acetone- $d_{6}$, $\delta$ in parts per million, $J$ in hertz. bOverlapping signals.

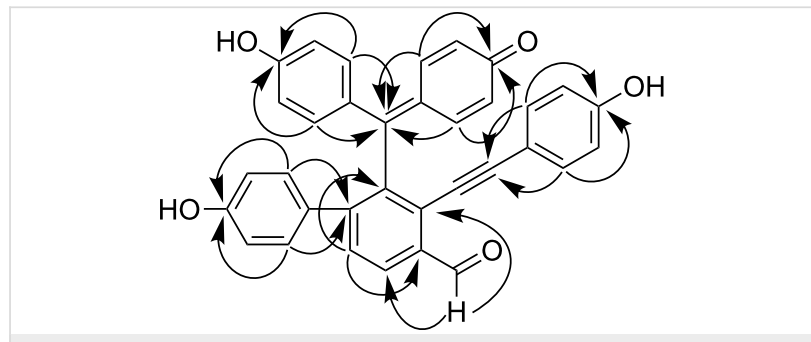

Figure 2: Key HMBC correlations of compound 1. 
hydroxyphenyl)ethynyl)biphenyl-2-yl)(4-hydroxyphenyl)methylene]cyclohexa-2,5-dien-1-one, named as selaginellin O.

The chemical structures of selaginellin M (2), selaginellin (3) and selaginellin A (4) were identified by spectral analysis by 1D and 2D NMR spectroscopy and high-resolution MS. Their ${ }^{1} \mathrm{H}$ and ${ }^{13} \mathrm{C}$ NMR data were assigned in Table 2.

Several species of the genus Selaginella have long been used in traditional medicine as anticancer agents, but only limited litera- ture information on the cytotoxic activity of their constituents is available, which encourages us to investigate the cytotoxic effect of the seleginellins [4,5,7]. The cytotoxic activities of the three selaginellins: selaginellin O (1), selaginellin M (2) and selaginellin (3) were evaluated by using human cervical carcinoma (HeLa) cells. It is noticeable that all of these selaginellins exhibited appreciable cytotoxic activity (Supporting Information File 1; Table S1). Selaginellin O (1), the new selaginellin with a formyl group, showed the highest inhibitory activity, with an $\mathrm{IC}_{50}$ value of $26.4 \mu \mathrm{M}$. Consistent with earlier litera-

Table 2: ${ }^{1} \mathrm{H}$ and ${ }^{13} \mathrm{C}$ NMR data for compound 2,3 and $4 .^{a}$

\begin{tabular}{|c|c|c|c|c|c|c|}
\hline & 2 & & 3 & & 4 & \\
\hline Position & $\delta_{\mathrm{H}}$ & $\delta_{C}$ & $\delta_{\mathrm{H}}$ & $\delta_{C}$ & $\delta_{H}$ & $\delta_{C}$ \\
\hline 1 & - & 185.7 & - & 173.1 & - & 185.9 \\
\hline 2 & $6.32 \mathrm{dd}(2.0,10.0)$ & 128.1 & $6.54 \mathrm{~d}(8.8)$ & 121.4 & $6.35 \mathrm{~m}$ & 128.2 \\
\hline 3 & $7.34 \mathrm{dd}(2.4,10.0)$ & 139.5 & $7.16 \mathrm{~d}(9.2)$ & 136.5 & $7.48 \mathrm{~d}(8.0)$ & 139.5 \\
\hline 4 & - & 129.7 & - & 130.2 & - & 128.4 \\
\hline 5 & $7.52 \mathrm{dd}(2.4,10.0)$ & 138.1 & $7.16 \mathrm{~d}(9.2)$ & 136.5 & $7.59 \mathrm{~d}(8.0)$ & 138.0 \\
\hline 6 & $6.36 \mathrm{dd}(2.0,10.0)$ & 130.2 & $6.54 \mathrm{~d}(8.8)$ & 121.4 & $6.35 \mathrm{~m}$ & 128.2 \\
\hline 7 & - & 158.1 & - & 160.1 & - & 158.0 \\
\hline 8 & $6.88 \mathrm{~d}(9.2)$ & 132.7 & $7.16 \mathrm{~d}(9.2)$ & 136.5 & $6.75 \mathrm{~d}(8.8)$ & 133.0 \\
\hline 9 & $6.66 \mathrm{~d}(8.8)$ & 113.2 & $6.54 \mathrm{~d}(8.8)$ & 121.4 & $6.64 \mathrm{~m}$ & 114.7 \\
\hline 10 & - & 160.8 & - & 173.1 & - & 158.8 \\
\hline 11 & $6.66 \mathrm{~d}(8.8)$ & 113.2 & $6.54 \mathrm{~d}(8.8)$ & 121.4 & $6.64 \mathrm{~m}$ & 114.7 \\
\hline 12 & $6.88 \mathrm{~d}(9.2)$ & 132.7 & $7.16 \mathrm{~d}(9.2)$ & 136.5 & $6.75 \mathrm{~d}(8.8)$ & 133.0 \\
\hline 13 & - & 131.7 & - & 130.2 & - & 133.5 \\
\hline 14 & - & 121.5 & - & 121.7 & - & 124.6 \\
\hline 15 & - & 142.7 & - & 142.5 & $7.67 \mathrm{~d}(8.0)$ & 130.2 \\
\hline 16 & $7.79 \mathrm{~d}(8.0)$ & 126.8 & $7.79 \mathrm{~d}(8.0)$ & 127.0 & $7.59 \mathrm{t}(7.6)$ & 129.1 \\
\hline 17 & $7.38 \mathrm{~d}(8.0)$ & 129.7 & $7.37 \mathrm{~d}(8.0)$ & 129.7 & $7.48 \mathrm{~d}(8.0)$ & 130.0 \\
\hline 18 & - & 140.9 & - & 141.3 & - & 143.0 \\
\hline 19 & - & 141.0 & - & 140.9 & - & 141.1 \\
\hline 20 & $6.91 \mathrm{~d}(8.4)$ & 130.2 & $6.87 \mathrm{~d}(8.4)$ & 129.9 & $6.89 \mathrm{~d}(8.4)$ & 129.8 \\
\hline 21 & $6.80 \mathrm{~d}(9.2)$ & 114.7 & $6.65 \mathrm{~d}(8.4)$ & 114.8 & $6.64 \mathrm{~m}$ & 114.7 \\
\hline 22 & - & 156.7 & - & 156.8 & - & 156.8 \\
\hline 23 & $6.80 \mathrm{~d}(9.2)$ & 114.7 & $6.65 \mathrm{~d}(8.4)$ & 114.8 & $6.64 \mathrm{~m}$ & 114.7 \\
\hline 24 & $6.91 \mathrm{~d}(8.4)$ & 130.2 & $6.87 \mathrm{~d}(8.4)$ & 129.9 & $6.89 \mathrm{~d}(8.4)$ & 129.8 \\
\hline 25 & - & 131.7 & - & 131.6 & - & 131.7 \\
\hline 26 & $5.01 \mathrm{~s}$ & 62.2 & $5.02 \mathrm{~s}$ & 62.2 & & \\
\hline 27 & - & 83.8 & - & 83.8 & - & 86.6 \\
\hline 28 & - & 98.8 & - & 99.0 & - & 93.5 \\
\hline 29 & $7.11 \mathrm{~d}(8.4)$ & 133.0 & $7.09 \mathrm{~d}(8.4)$ & 133.0 & $7.09 \mathrm{~d}(8.8)$ & 133.1 \\
\hline 30 & $6.76 \mathrm{~d}(8.8)$ & 115.5 & $6.75 \mathrm{~d}(8.4)$ & 115.6 & $6.74 \mathrm{~d}(8.4)$ & 115.5 \\
\hline 31 & - & 157.8 & - & 158.4 & - & 158.0 \\
\hline 32 & $6.76 \mathrm{~d}(8.8)$ & 115.5 & $6.75 \mathrm{~d}(8.4)$ & 115.6 & $6.74 \mathrm{~d}(8.4)$ & 115.5 \\
\hline 33 & $7.11 \mathrm{~d}(8.4)$ & 133.0 & $7.09 \mathrm{~d}(8.4)$ & 133.0 & $7.09 \mathrm{~d}(8.8)$ & 133.1 \\
\hline 34 & - & 113.6 & - & 113.3 & - & 113.6 \\
\hline$-\mathrm{OMe}$ & $3.79 \mathrm{~s}$ & 54.8 & & & & \\
\hline
\end{tabular}

\footnotetext{
${ }^{a} 400 \mathrm{MHz}$, acetone- $d_{6}$, $\delta$ in parts per million, $J$ in hertz.
} 
ture [20], the considerable inhibition of the expression of HeLa cells was observed for the known compounds selaginellin M (2) and selaginellin (3), with $\mathrm{IC}_{50}$ equal to 28.5 and $33.1 \mu \mathrm{M}$, respectively.

Over the past few decades, considerable biochemical, physiological and pharmacological evidence has accumulated to support the hypothesis that free-radical-mediated oxidative processes are implicated in various human diseases. The role of free radicals in ageing, in cancer, and in cardiovascular, neurodegenerative and other diseases is more and more widely accepted $[21,22]$. Antioxidants are attracting increasing scientific and clinical attention.

Natural phenolic compounds (flavonoids, lignans, phenolic acids, tocopherols, polyphenols and tannins) are the main class of antioxidants and are known to reduce the rate of oxidation by $\mathrm{H}$-transfer (from their phenol groups) to the radicals [23]. There are multiple phenol groups on the large conjugated aromatic skeleton of selaginallins, and this potential antioxidant structural feature motivated the study on their antioxidant activity. Accordingly, the antioxidant capacity of selaginellin O (1), selaginellin M (2) and selaginellin (3) were estimated with the widely used ABTS radical-scavenging assay and FRAP assay. In both assays, all the selaginellins tested displayed significant antioxidant activity, with more potent antioxidant capacity than the reference compound Trolox (Supporting Information File 1; Table S2). Likewise, the new compound, selaginellin O (1), exhibited the highest antioxidant activity, and a general increase in antioxidant activity was observed compared with its reduced form selaginellin (3). This may be correlated with the electronaccepting and delocalization effects of the formyl group, which favor the ionization of $\mathrm{ArOH}$ to the phenoxide anion $\mathrm{ArO}^{-}$, benefitting from both $\mathrm{H}$-transfer and stabilization of the important mediator $\mathrm{ArO}^{-}$. The above two main factors of the antioxidant contribute to the potent antioxidant properties of selaginallin $\mathrm{O}$.

The current pharmacological evidence shows that antioxidant treatment may significantly inhibit atherosclerosis, which indicates that selaginallins may be partly related to the herbal use of $S$. tamariscina for promoting blood circulation and eliminating blood stasis [24].

Despite its preliminary character, this study is the first to report the antioxidant activity of the selaginellins. These promising biological results and the structural specificity of the selaginellins stimulated us to search for more potent and selective selaginellin analogues and their biogenetic precursors. Additional controlled studies are needed to investigate the efficacy and safety of selaginellins as antioxidant and anticancer agents.

\section{Experimental}

General experimental procedures. IR spectra were measured on a Perkin Elmer Spectrum 100 FT-IR Spectrometer. All NMR spectra data were recorded on a Bruker $400 \mathrm{MHz}$ AVANCE III FT-NMR spectrometer operating at $400 \mathrm{MHz}$ for ${ }^{1} \mathrm{H}$ and $100 \mathrm{MHz}$ for ${ }^{13} \mathrm{C}$ NMR by using TMS as the internal standard. HRMS-ESI spectrum was obtained on an Agilent 1200-6520 QTOF. UV spectra were recorded on a Perkin Elmer LAMBDA $750 \mathrm{UV} / \mathrm{Vis} / \mathrm{NIR}$ spectrophotometer. The melting point was measured by Büchi B-540 Melting Point Apparatus. Optical rotations were measured with a WZZ-3 automatic Polarimeter. Column chromatography was performed over silica gel (200-300 mesh). Thin-layer chromatography (TLC) was conducted on precoated silica gel plates $\mathrm{GF}_{254}$ (Qingdao Marine Chemical Factory). 3-(4,5-Dimethylthiazol-2-yl)-2,5diphenyltetrazolium bromide (MTT), cisplatin, and 2,4,6-tri(2pyridyl)-1,3,5-triazine (TPTZ) were from Aladdin Reagent Co. Ltd. 2,2'-azinobis(3-ethylbenzothiazoline-6-sulfonic acid) diammonium salt (ABTS) and 6-hydroxy-2,5,7,8-tetramethylchroman-2-carboxylic acid (Trolox) were obtained from Sigma.

Plant material. The herb of Selaginella tamariscina was purchased from Tongtai Medicine, Harbin Co. Ltd., China. The material was authenticated by Prof. Zhenyue Wang, Heilongjiang University of Chinese Medicine. A voucher specimen (No. 200705JB) was deposited in the Lab of Applied Organic Chemistry, Harbin Institute of Technology.

Extraction and isolation. Dried whole herb of $S$. tamariscina $(5.0 \mathrm{~kg})$ was pulverized and extracted with methanol $(3 \times 5.0 \mathrm{~L})$ at room temperature. The combined methanolic extract was concentrated in vacuum giving a dark residue $(605 \mathrm{~g})$, which was partitioned into five fractions, petroleum ether $(80 \mathrm{~g}), \mathrm{Et}_{2} \mathrm{O}$ (41 g), EtOAc (112 g), $\mathrm{Me}_{2} \mathrm{CO}$ (96 g) and $\mathrm{MeOH}$ (221 g), by silica-gel column chromatography. The ethyl acetate fraction (112 g) was chromatographed on silica gel (chloroform/ methanol $1: 0 \rightarrow 0: 1)$ to afford fractions $1-20$. Fraction 15 (600 mg) was resubjected to silica gel CC with gradient petrol ether/acetone $(10: 1 \rightarrow 0: 1)$ to give amentoflavone $(328.4 \mathrm{mg})$ and some red powder, which was then further purified on PTLC (petrol ether/acetone $4: 1)$ to afford selaginellin M (2) (1.83 mg) and selaginellin $\mathrm{O}$ (1) (2.37 mg). Selaginellin (3) (83.0 mg) and selaginellin A (4) (0.7 mg) were obtained from fraction 16 (152 mg) by CC (silica gel; petrol ether/ethyl acetate 10:1, 5:1, $2: 1,1: 1$ and $1: 5$ ), followed by PTLC (chloroform/methanol $15: 1)$.

Selaginellin O (1): Red powder; UV (MeOH) $\lambda_{\max }(\log \varepsilon): 298$ (3.15), 415 (1.8) nm; IR (NaCl) v $v_{\max }: 3378,2198,2829,2817$, 1726, 1680, 1567 and $1524 \mathrm{~cm}^{-1} ;{ }^{1} \mathrm{H}$ and ${ }^{13} \mathrm{C}$ NMR (DEPT) 
data were shown in Table 1; HRMS-ESI $(\mathrm{m} / \mathrm{z}):[\mathrm{M}+\mathrm{H}]^{+}$calcd for $\mathrm{C}_{34} \mathrm{H}_{23} \mathrm{O}_{5}{ }^{+}, 511.1540$; found, 511.1543 .

Selaginellin M (2): Red powder; UV (MeOH) $\lambda_{\max }(\log \varepsilon): 297$ (3.15), 431 (1.05); IR (NaCl) $v_{\max }: 3420,2196,1708,1545$ and $1535 \mathrm{~cm}^{-1} ;{ }^{1} \mathrm{H}$ and ${ }^{13} \mathrm{C}$ NMR (DEPT) data were shown in Table 2; HRMS-ESI $(\mathrm{m} / \mathrm{z}):[\mathrm{M}+\mathrm{H}]^{+}$calcd for $\mathrm{C}_{35} \mathrm{H}_{27} \mathrm{O}_{5}{ }^{+}$, 527.1853; found, 527.1868 .

Selaginellin (3): Red crystals (MeOH); IR (NaCl) $v_{\text {max }}$ : 3387 , 2195, 1689, 1595 and $1531 \mathrm{~cm}^{-1} ;{ }^{1} \mathrm{H}$ and ${ }^{13} \mathrm{C}$ NMR data were shown in Table 2; HRMS-ESI $(\mathrm{m} / \mathrm{z})$ : $[\mathrm{M}+\mathrm{H}]^{+}$calcd for $\mathrm{C}_{34} \mathrm{H}_{25} \mathrm{O}_{5}{ }^{+}, 513.1697$; found, 513.1702.

Selaginellin A (4): Red powder; IR (NaCl) $v_{\max }$ : 3404, 2205, 1656, 1575 and $1531 \mathrm{~cm}^{-1} ;{ }^{1} \mathrm{H}$ and ${ }^{13} \mathrm{C}$ NMR data were shown in Table 2; HRMS-ESI $(\mathrm{m} / \mathrm{z}):[\mathrm{M}+\mathrm{H}]^{+}$calcd for $\mathrm{C}_{33} \mathrm{H}_{23} \mathrm{O}_{4}{ }^{+}$, 483.1591; found, 483.1587.

Cytotoxicity assay. Due to insufficient material, selaginellin O (1), selaginellin M (2) and selaginellin (3), were evaluated for their cytotoxic activity against cultured human cervical carcinoma HeLa cells by using the MTT [3-(4,5-dimethylthiazol-2yl)-2,5-diphenyltetrazolium bromide] colorimetric method [25]. The anticancer agent cisplatin was used as a positive control. The cytotoxicity data were expressed as $\mathrm{IC}_{50}$ (half inhibition concentration) values.

ABTS radical scavenging assay. The assay was performed according to the established protocol [26]. The $\mathrm{ABTS}^{\bullet+}$ radical was generated by mixing $7 \mathrm{mM}$ aqueous ABTS solution with $2.45 \mathrm{mM}$ potassium persulfate solution (final concentration) followed by incubation in the dark at room temperature for $16 \mathrm{~h}$. The resultant $\mathrm{ABTS}^{\circ+}$ solution was diluted with ethanol to give an absorbance of $0.70 \pm 0.02$ at $734 \mathrm{~nm}$ and equilibrated at $30{ }^{\circ} \mathrm{C}$. After the addition of $2.85 \mathrm{~mL}$ of diluted $\mathrm{ABTS}^{\cdot+}$ solution to $0.15 \mathrm{~mL}$ of different concentrations of samples in ethanol, the absorbance reading was taken at $30^{\circ} \mathrm{C}$, exactly 6 min after the initial mixing. The percentage inhibition of absorbance at $734 \mathrm{~nm}$ was calculated and plotted as a function of the concentration of samples and of Trolox as standard. The antioxidant activities are expressed as the $\mathrm{IC}_{50}$ value.

FRAP (Ferric reducing antioxidant power) assay. This assay was carried out following the procedure described previously with modifications [27]. FRAP reagent was prepared fresh by mixing $10 \mathrm{mM}$ TPTZ, $20 \mathrm{mM} \mathrm{FeCl}_{3}$ and $300 \mathrm{mM}$ acetate buffer $(\mathrm{pH} 3.6)$ in a $1: 1: 10(\mathrm{v} / \mathrm{v} / \mathrm{v})$ ratio and warmed to $37^{\circ} \mathrm{C}$ before use. A $0.2 \mathrm{~mL}$ amount of the sample including Trolox as a reference compound in methanol was added to $1.8 \mathrm{~mL}$ freshly prepared FRAP reagent and then incubated at $37^{\circ} \mathrm{C}$ for $8 \mathrm{~min}$.

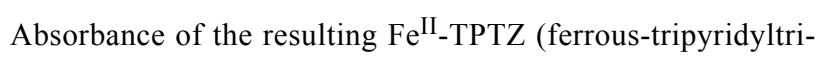
azine) complex was measured at $595 \mathrm{~nm}$. Antioxidant power was expressed as micromolar Fe $\mathrm{II}_{-}^{\mathrm{II}} \mathrm{TPZ}$ equivalents, calculated from a calibration curve prepared with various concentrations of $\mathrm{FeSO}_{4}$.

\section{Supporting Information}

\section{Supporting Information File 1}

Spectroscopic data and other relevant information for compounds 1-4.

[http://www.beilstein-journals.org/bjoc/content/ supplementary/1860-5397-8-217-S1.pdf]

\section{Acknowledgements}

Financial support from China NSFC (No. 21002018), the Fundamental Research Funds for the Central Universities (No. HIT.BRET2.2010001), HIT.NSRIF (Nos. 01107866 and 01107986), and the program of excellent Team in HIT are gratefully acknowledged.

\section{References}

1. Editorial Committee of FRPS. Flora Reipublicae Popularis Sinicae; Science Press: Beijing, China, 1978; Vol. 6(3), pp 100-104.

2. Dai, Z.; Wang, G. L.; Hou, Q. Y.; Ni, L.; Wei, F.; Lin, R. C. Chin. Trad. Herb. Drugs 2001, 32, 784-785.

3. Chinese Pharmacopoeia Commission. Pharmacopoeia of the People's Republic of China; People's Medical Publishing House: Beijing, China, 2010; Vol. 1, pp 210-211.

4. Silva, G. L.; Chai, H.; Gupta, M. P.; Farnsworth, N. R.; Cordell, G. A.; Pezzuto, J. M.; Beecher, C. W. W.; Kinghorn, A. D. Phytochemistry 1995, 40, 129-134. doi:10.1016/0031-9422(95)00212-P

5. Chen, J.-J.; Duh, C.-Y.; Chen, J.-F. Planta Med. 2005, 71, 659-665. doi:10.1055/s-2005-871273

6. Lee, C.-W.; Choi, H.-J.; Kim, H.-S.; Kim, D.-H.; Chang, I.-S.; Moon, H. T.; Lee, S.-Y.; Oh, W. K.; Woo, E.-R. Bioorg. Med. Chem. 2008, 16, 732-738. doi:10.1016/j.bmc.2007.10.036

7. Cao, Y.; Tan, N.-H.; Chen, J.-J.; Zeng, G.-Z.; Ma, Y.-B.; Wu, Y.-P.; Yan, H.; Yang, J.; Lu, L.-F.; Wang, Q. Fitoterapia 2010, 81, 253-258. doi:10.1016/j.fitote.2009.09.007

8. Wang, Y. Z.; Chen, H.; Zheng, X. K.; Feng, W. S. Chin. Chem. Lett. 2007, 18, 1224-1226. doi:10.1016/j.cclet.2007.08.016

9. Feng, W.-s.; Li, K.-k.; Zheng, X.-k. Acta Pharm. Sinica B 2011, 1, 36-39. doi:10.1016/j.apsb.2011.04.001

10. Chao, L. R.; Seguin, E.; Tillequin, F.; Koch, M. J. Nat. Prod. 1987, 50, 422-426. doi:10.1021/np50051a013

11. Wang, Y.-H.; Long, C.-L.; Yang, F.-M.; Wang, X.; Sun, Q.-Y.; Wang, H.-S.; Shi, Y.-N.; Tang, G.-H. J. Nat. Prod. 2009, 72, 1151-1154. doi:10.1021/np9001515

12. Zheng, X.; Du, J.; Xu, Y.; Zhu, B.; Liao, D. Fitoterapia 2007, 78, 598-599. doi:10.1016/j.fitote.2007.04.008

13. Zhang, L.-P.; Liang, Y.-M.; Wei, X.-C.; Cheng, D.-L. J. Org. Chem. 2007, 72, 3921-3924. doi:10.1021/jo0701177 
14. Cheng, X.-L.; Ma, S.-C.; Yu, J.-D.; Yang, S.-Y.; Xiao, X.-Y.; Hu, J.-Y.; Lu, Y.; Shaw, P.-C.; But, P. P.-H.; Lin, R.-C. Chem. Pharm. Bull. 2008, 56, 982-984. doi:10.1248/cpb.56.982

15. Tan, G.-S.; Xu, K.-P.; Li, F.-S.; Wang, C.-J.; Li, T.-Y.; Hu, C.-P.; Shen, J.; Zhou, Y.-J.; Li, Y. J. J. Asian. Nat. Prod. Res. 2009, 11, 1001-1004. doi:10.1080/10286020903207043

16. Cao, Y.; Chen, J.-J.; Tan, N.-H.; Wu, Y.-P.; Yang, J.; Wang, Q. Magn. Reson. Chem. 2010, 48, 656-659. doi:10.1002/mrc.2623

17. Cao, Y.; Chen, J.-J.; Tan, N.-H.; Oberer, L.; Wagner, T.; Wu, Y.-P.; Zeng, G.-Z.; Yan, H.; Wang, Q. Bioorg. Med. Chem. Lett. 2010, 20, 2456-2460. doi:10.1016/j.bmcl.2010.03.016

18. Xu, K.-P.; Zou, H.; Tan, Q.; Li, F.-S.; Liu, J.-F.; Xiang, H.-L.; Zou, Z.-X.; Long, H.-P.; Li, Y.-J.; Tan, G.-S. J. Asian. Nat. Prod. Res. 2011, 13, 93-96. doi:10.1080/10286020.2010.536535

19. Xu, K.-P.; Zou, H.; Li, F.-S.; Xiang, H.-L.; Zou, Z.-X.; Long, H.-P.; Li, J.; Luo, Y.-J.; Li, Y.-J.; Tan, G.-S. J. Asian. Nat. Prod. Res. 2011, 13, 356-360. doi:10.1080/10286020.2011.558840

20.Zhang, G.-g.; Jing, Y.; Zhang, H.-m.; Ma, E.-I.; Guan, J.; Xue, F.-n.; Liu, H.-x.; Sun, X.-y. Planta Med. 2012, 78, 390-392. doi:10.1055/s-0031-1298175

21. Poon, H. F.; Calabrese, V.; Scapagnini, G.; Butterfield, D. A. Clin. Geriatr. Med. 2004, 20, 329-359. doi:10.1016/j.cger.2004.02.005

22. Abrescia, P.; Golino, P. Expert. Rev. Cardiovasc. Ther. 2005, 3 , 159-171. doi:10.1586/14779072.3.1.159

23. Rahman, K. Clin. Interv. Aging 2007, 2, 219-236.

24. Foti, M. C. J. Pharm. Pharmacol. 2007, 59, 1673-1685. doi:10.1211/jpp.59.12.0010

25. Pagé, M.; Bejaoui, N.; Cinq-Mars, B.; Lemieux, P. Int. J. Immunopharmacol. 1988, 10, 785-793. doi:10.1016/0192-0561(88)90001-X

26. Re, R.; Pellegrini, N.; Proteggente, A.; Pannala, A.; Yang, M.; Rice-Evans, C. Free Radical Biol. Med. 1999, 26, 1231-1237. doi:10.1016/S0891-5849(98)00315-3

27. Benzie, I. F. F.; Strain, J. J. Anal. Biochem. 1996, 239, 70-76. doi:10.1006/abio.1996.0292

\section{License and Terms}

This is an Open Access article under the terms of the Creative Commons Attribution License (http://creativecommons.org/licenses/by/2.0), which permits unrestricted use, distribution, and reproduction in any medium, provided the original work is properly cited.

The license is subject to the Beilstein Journal of Organic Chemistry terms and conditions:

(http://www.beilstein-journals.org/bjoc)

The definitive version of this article is the electronic one which can be found at: $\underline{\text { doi:10.3762/bjoc. } 8.217}$ 